\section{Greenhouse Performance of Six Potted Anthurium Cultivars in a Subtropical Area}

\author{
Yin-Tung Wang
}

ADDITIONAL INDEX WORDS. floriculture potted plants, temperature, growth regulator

Summary. Vegetatively propagated liners of six hybrid anthurium cultivars (A nthurium Schott), 'Pink Aristocrat', 'Patty Anne', 'Purple Viking', 'R oyal Pink', R oyal Orange', and 'R oyal Red', were planted in pots and grown under warm [maximum $30^{\circ} \mathrm{C}\left(86^{\circ} \mathrm{F}\right)$ ] or hot [maximum $35^{\circ} \mathrm{C}$ or $\left(95^{\circ} \mathrm{F}\right)$ ] conditions with or without a single foliar application of $500 \mathrm{mg} \cdot \mathrm{L}^{-1}(\mathrm{ppm})$ $\mathrm{G} \mathrm{A}_{3}$ and evaluated after 7,9 , and 13 months. $\mathrm{GA}_{3}$, when applied 7 months after planting, did not promote flower production or result in taller plants. Plants in warm and hot areas, except for 'Pink Aristocrat', had similar degrees of foliage injury in April, but those in the warm environment had better quality in July than those in the hothouse. Yellow leaves and necrosis on leaf margins were apparent on plants in the hot area. 'Pink Aristocrat' was the most (>20 flowers) and 'R oyal Red' was the least (2 flowers) floriferous after 1 year. Flower color of ' $R$ oyal Red' was unaffected by high temperature, whereas flowers of the other cultivars faded under heat. $G$ rowing these anthurium cultivars at maximum $30{ }^{\circ} \mathrm{C}\left(86^{\circ} \mathrm{F}\right)$ air temperatures is recommended for good quality and high flower count.

A nthurium plants have leathery, shiny leaves and flowers of various bright colors,

Department of $\mathrm{H}$ orticultural Sciences, Texas $\mathrm{A} \& \mathrm{M}$ U niversity System Agricultural Research and Extension Center, 2415 East Highway 83, Weslaco, TX 78596.

I greatly appreciate Twyford L aboratories, Inc. Santa Paula, Calif., for providing the plant materials and partial funding for conducting this experiment. The cost of publishing this paper was defrayed in part by the payment of page charges. U nder postal regulations, this paper must hereby be marked adverti sement solely to indicate this fact. making them very attractive to consumers. For many years, anthurium was produced almost strictly for cut flowers with limited use as a container plant because of its large size. 'Arabella' is a dwarf plant and does quite well in a greenhouse between $\mathrm{O}$ ctober and $M$ arch. $H$ owever, it developssevereleaf injury when grown in south Texas during the summer, rendering plants unmarketable. In recent years, new cultivars suitable for pot production have been developed. Thesecultivarsneed to be tested for their possible commercial production as potted plants in warm production areas. Gibberellic acid has been found to promoteflower initiation and production in several aroid genera, including Anthurium ( $\mathrm{H}$ enny and H amilton, 1992), Caladium (H arbaugh and Wilfret, 1979), and Zantedeschia (Corr and Widmer, 1987). The effect of $\mathrm{GA}_{3}$ on promoting flowering of six potted anthurium cultivars was also studied.

\section{Materials and methods}

Vegetatively propagated liners of six hybrid anthurium cultivars, 'Pink Aristocrat', 'Patty Anne', 'Purple Viking', 'R oyal Pink', R oyal O range', and 'Royal Red', were received (Twyford Laboratories, Santa Paula, Calif.) and potted on 17 July 1993 in $11.4-\mathrm{cm}$ (4.5-inch) round plastic pots $(0.5 \mathrm{~L}$ or 0.13 gal in volume) using SunshineN 0 . 1 (Fisons H orticulture, Seattle, Wash.). Sixteen uniform plants of each cultivar were selected and separated into two groups of eight plants each with one group being placed in a warm greenhouse and the other in a hot house. $D$ aytime maximum air temperature in the warm house remained at or below $30^{\circ} \mathrm{C}\left(86^{\circ} \mathrm{F}\right)$ in the summer and the minimum night temperature was at or above $17{ }^{\circ} \mathrm{C}\left(62.6^{\circ} \mathrm{F}\right)$ in the winter. $D$ ailyhigh temperaturesin thehothouse were generally $\left[2^{\circ} \mathrm{C}\left(3.8^{\circ} \mathrm{F}\right)\right.$ in winter to $4{ }^{\circ} \mathrm{C}\left(7.2^{\circ} \mathrm{C}\right)$ in summer] warmer

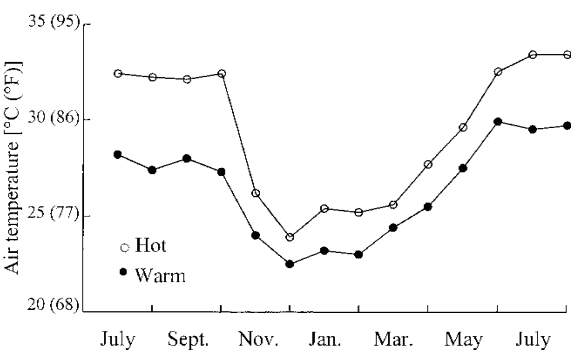

Fig. 1. Average monthly maximal air temperatures in the hot and warm greenhouses. than the warm house (Fig. 1). Plants were transplanted to $15-\mathrm{cm}$ pots $(1.75$ $\mathrm{L}$ or $0.46 \mathrm{gal}$ in volume) on $3 \mathrm{Nov}$. 1993 in Sunshine N o. 1.

All plants received a midday maximum photosynthetic photon flux (PPF) between $240 \mu \mathrm{mol} \cdot \mathrm{m}^{-2} \cdot \mathrm{s}^{-1}$ $(\approx 1200 \mathrm{f}-\mathrm{c})$ in anuary and $370 \mu \mathrm{mol} \cdot \mathrm{m}$ $2.5^{1}(\approx 1860 \mathrm{f}-\mathrm{c})$ in July. They were given Peters 24N-3.4P-13.3K (24-816, W.R. G race, Foglesville, Pa.) at therate of $0.84 \mathrm{~g} \cdot \mathrm{L}^{-1}(0.11 \mathrm{oz} / \mathrm{gal})$ with every irrigation. Water from a reverse osmosis (RO) device[ electrical conductivity (EC) $\left.<0.05 \mathrm{dS} \cdot \mathrm{m}^{-1}\left(\mathrm{mmho}^{\circ} \mathrm{cm}^{-1}\right)\right]$ wasused for irrigation until $10 \mathrm{ct}$. when it became necessary to switch to municipal water $\left(E C=1.4 \mathrm{dS} \cdot \mathrm{m}^{-1}\right.$ or $\left.\mathrm{mmho} \cdot \mathrm{cm}^{-1}\right)$, and back to RO water on 18 J an. the following year.

The experiment was a randomized complete block design within each cultivar. In each temperature treatment, there was one pair of plants in each of the four blocks. The first evaluation was conducted on 19 Feb. 1994. O ne plant in each of the four pairs was sprayed to incipient run off with $\mathrm{GA}_{3}$ at $500 \mathrm{mg} \cdot \mathrm{L}^{-1}$ (ppm) on 24 Feb. 1994 to determineits effect on flower production. $D$ ata were collected again on 23 A pr. 1994, after 9 months of production. Final evaluation was performed on 24 Aug. 1994.

Each plant was evaluated for plant height (from pot rim to the highest point), flower height (from the base of aflowering stem to thetip of itsflower), cumulative flower count, foliage injury, plant grade, and root vigor. I n addition, plant characteristics, including shapeand color of leaves and flowers, were re corded.

\section{Results}

The descriptions of plant characteristics are given in Table 1. Plants in the 'R oyal' series had more basal shoots and substantially larger flowers than the other three cultivars. $\mathrm{GA}_{3}$ neither promoteflowering nor resulted in increased plantheight; therefore, datawerepooled to show the temperature effects only.

'Pink Aristocrat' is a very showy cultivar producing an abundanceofflowers (Tables 2 and 3; 8 flowers in 9 months) rising well above the foliage (Tables 3 and 4). I t was the earliest one to bloom and had less foliage injury under the warm environment (T ables2, 3 , and 4). When grown in the warm area, the plants' long triangular leaves had slight marginal yellowing, but no tip injury. $\mathrm{H}$ ot-grown plants had much 
T able 1. The characteristics of six potted anthurium cultivars.

\begin{tabular}{|c|c|c|c|c|c|c|c|}
\hline \multirow[b]{2}{*}{ Cultivar } & \multicolumn{3}{|c|}{ Leaf } & \multicolumn{3}{|c|}{ F lower } & \multirow{2}{*}{$\begin{array}{l}\text { Plant } \\
\text { shape }\end{array}$} \\
\hline & Size & Shape & G reen & Size & Color & Shape & \\
\hline Pink Aristocrat & M edium & Triangular & M edium & M edium & Pink & Drop & O pen \\
\hline Patty Anne & Large & Triangular & M edium & M edium & Lavender & Drop & Open \\
\hline Purple Viking & M edium & Triangular & M edium & M edium & Purple & Drop & O pen \\
\hline Royal O range & Large & $\mathrm{H}$ eart & Dark & Large & Orange & $\mathrm{H}$ eart & D ense \\
\hline Royal Pink & Large & $\mathrm{H}$ eart & Dark & Large & Light red & H eart & U pright \\
\hline Royal Red & Small & $\mathrm{H}$ eart & Dark & Large & D eep red & $\mathrm{H}$ eart & Compact \\
\hline
\end{tabular}

severe leaf yellowing and tip injury and a reduction in root vigor (T able 3 ). The flowersof 'Pink Aristocrat' plantsgrown in the hot house tended to fade early.

'Patty Anne' has spreading foliage and its teardrop shaped flowers are pale lavender. The flowers (2.8/ plant in 9 months; Table 3) rose high above the foliage (Tables 3 and 4) and did not droop. In the warm area, this cultivar had long, slightly heart shaped leaves that developed slight injury on the margins. When grown under the hot condition, plants had long, wide leaves with extensiveleaf edgeburn, the foliagewas sparse, and the flowers were pale.

'PurpleV iking' haslong, largedullgreen leaves with open foliage. Plants have teardrop-shaped, lavender flowers that unfold at the foliage height and are sometimes blocked from view by the foliage (Table 3 ). When grown under hot conditions, leaf tip and margin injurywasapparent. 'PurpleV iking' grown in the hot area had extreme leaf yellowing with sparse, short foliage (T able 4). These plantshad smaller spathes, which faded and were duller than those pro- duced in thewarm house. Flower count averaged only 2.5 per plant following 9 months of production.

All of theabovecultivarshad slightly droopy leaves when grown in the hot area. Plants were taller in the warm house. In general, flowers of these three cultivars were held above foliage that is highly desirable.

'R oyal Pink' haslarge, heart-shaped leaves. The plant had dense foliage and young leaves had a slight red tint. The pinkish-red flowers (only 1.3/ plant in Apr. 1994; Table 2) were large and brightly colored. Flowers opened at or just below the foliage (Tables 3 and 4) and remained upright. When exposed to the hot air, the foliage had a copper tint and was severely mottled, but the flowers remained bright pink-red.

'Royal O range' hasadenseupright growth habit with shiny, heart-shaped leaves and flowers. The flowers (1.7 per plant) opened at foliage level (Table 3 and 4), but some drooped down and were hidden by the dense foliage. $\mathrm{H}$ otgrown plants had a reduction in average plant size, but retained the shiny leaves and flowers. In addition, more leaf tip injury and leaf yellowing were present when grown under the hot conditions.

'Royal Red' has smaller heartshaped leaves and denser, more compact foliagethan 'Royal Pink' and 'R oyal $O$ range'. Flowersare deep red and heartshaped that opened at foliage height (Tables 3 and 4). The leaves were shiny with littleor no injury in either thewarm or the hot areas until the last evaluation, when leaf injury was apparent on plants in the hot area. L eaves were deep green and plants were vigorous. O nly one plant of thiscultivar flowered by theend of A pril 1994. Flower count was low when all plants had bloomed.

The 'Royal Pink', 'Royal O range', and 'Royal Red' cultivars have numerous basal shoots, giving them dense foliage at the base. Again, plants produced in the hot area were shorter than those under the warm environment.

When evaluated in late August, 13 months following planting, plants that were grown in the warm house were taller and had more and/ or taller flowers than those in the hot house, except

Table 2. G rowth and flowering of six anthurium cultivars eval uated 7 months after planting of tissue-culture liners $(2.54 \mathrm{~cm}$ $=1$ inch).

\begin{tabular}{|c|c|c|c|c|c|c|}
\hline C ultivar & $\begin{array}{l}\text { G rowing } \\
\text { condition }\end{array}$ & $\begin{array}{c}\text { Plant } \\
\text { ht } \\
\text { (cm) }\end{array}$ & $\begin{array}{l}\text { Total } \\
\text { flower } \\
\text { count }\end{array}$ & $\begin{array}{c}\text { Leaf tip } \\
\text { injury } \\
(1-5)^{2} \\
\end{array}$ & $\begin{array}{l}\text { Plant } \\
\text { grade } \\
(1-5)^{y}\end{array}$ & $\begin{array}{l}\text { Root } \\
\text { vigor } \\
(1-5)^{x}\end{array}$ \\
\hline \multirow[t]{2}{*}{ Pink Aristocrat } & Warm & 17.9 & 5.5 & $3.8^{* *}$ & $4.5^{*}$ & $3.8^{*}$ \\
\hline & $\mathrm{H}$ ot & 13.7 & 2.5 & 2.0 & 1.8 & 2.3 \\
\hline \multirow[t]{2}{*}{ Patty Anne } & Warm & $19.2^{*}$ & 1.8 & 3.3 & 3.0 & $4.0^{* *}$ \\
\hline & $\mathrm{H}$ ot & 14.8 & 1.0 & 3.0 & 2.7 & 3.0 \\
\hline \multirow[t]{2}{*}{ Purple Viking } & Warm & 18.4 & 1.3 & 2.5 & 3.0 & 3.3 \\
\hline & $\mathrm{H}$ ot & 13.5 & 0.8 & 1.8 & 1.8 & 3.0 \\
\hline \multirow[t]{2}{*}{ Royal Pink } & Warm & 28.8 & 0.3 & 4.8 & 5.0 & 4.0 \\
\hline & $\mathrm{H}$ ot & 27.9 & 0.3 & 4.8 & 4.5 & 4.0 \\
\hline \multirow{2}{*}{ Royal O range } & Warm & $27.1^{*}$ & 1.5 & $5.0^{*}$ & 5.0 & 3.8 \\
\hline & $\mathrm{H}$ ot & 19.7 & 0.3 & 3.5 & 4.3 & 3.5 \\
\hline \multirow[t]{2}{*}{ Royal Red } & Warm & 24.8 & 0 & 5.0 & 5.0 & 3.8 \\
\hline & $\mathrm{H}$ ot & 19.3 & 0 & 4.8 & 5.0 & 3.5 \\
\hline
\end{tabular}

$\mathrm{z} 5=\mathrm{N}$ o injury to 1 = severe injury.

y $5=$ Excellent, 4 =good, $3=$ marketable, 2 = unmarketable, $1=$ very poor.

$\times 5=\mathrm{H}$ ealthy root system to $1=$ no roots on the surface of the medium.

${ }^{*, * *}$ Significant within a cultivar at $\mathrm{P}=0.05$ or 0.01 , respectively. 
Table 3. Six potted anthurium cultivars evaluated on 24 Apr., 9 months after planting of tissue-culture liners $(2.54 \mathrm{~cm}=$ 1 inch).

\begin{tabular}{|c|c|c|c|c|c|c|}
\hline Cultivar & $\begin{array}{l}\text { Growing } \\
\text { condition }\end{array}$ & $\begin{array}{c}\text { Plant } \\
\text { ht } \\
(\mathrm{cm})\end{array}$ & $\begin{array}{c}\text { Flower } \\
\text { ht } \\
(\mathrm{cm})\end{array}$ & $\begin{array}{c}\text { C umulative } \\
\text { flower } \\
\text { count }\end{array}$ & $\begin{array}{l}\text { Leaf } \\
\text { injury } \\
(1-5)^{z}\end{array}$ & $\begin{array}{l}\text { R oot } \\
\text { vigor } \\
(1-5)^{y}\end{array}$ \\
\hline Pink A ristocrat & $\mathrm{H}$ ot & 18.9 & 28.3 & 7.9 & 3.6 & 2.0 \\
\hline \multirow[t]{2}{*}{ Patty Anne } & Warm & $26.0^{*}$ & $43.9^{*}$ & 2.8 & 3.6 & $5.0^{*}$ \\
\hline & $\mathrm{H}$ ot & 22.4 & 33.4 & 2.8 & 3.5 & 4.0 \\
\hline \multirow[t]{2}{*}{ Royal Pink } & Warm & $40.0^{*}$ & 36.6 & 1.6 & 5.0 & 5.0 \\
\hline & $\mathrm{H}$ ot & 31.9 & 32.9 & 1.5 & 4.5 & 3.0 \\
\hline \multirow[t]{2}{*}{ Royal Orange } & Warm & $32.2^{*}$ & 28.4 & 1.8 & 5.0 & $4.0 *$ \\
\hline & $\mathrm{H}$ ot & 26.2 & 23.4 & 1.5 & 4.5 & 3.0 \\
\hline Royal Red & Warm & 27.1 & --- & 0.1 & 5.0 & 5.0 \\
\hline
\end{tabular}

$\mathrm{z} 5=\mathrm{N} 0$ injury to 1 = severe injury.

y5 $=\mathrm{H}$ ealthy root system to $1=$ no roots on the surface of the medium.

*Significant within a cultivar at $\mathrm{P}=0.05$.

the 'R oyal Pink'. Flower color of 'Pink Aristocrat' and 'Patty Anne' was similarly light under both environments. The deep red color of 'R oyal Red' flowers did not fade with the high temperature (Table 4), whereas flowers of the abovethree cultivars had better color in the warm than the hot house. O verall plant grade was higher for those produced in the warm house, regardless of cultivar.

\section{Discussion}

$M$ any of the new anthurium cultivars can be grown in a greenhouse in subtropical climates if certain cultural practicesarefollowed. A warm environment with air temperature not to exceed $30^{\circ} \mathrm{C}\left(86^{\circ} \mathrm{F}\right)$ is desirable for plant vigor and high quality. $O$ f the cultivarstested, 'Purple Viking' and 'Patty Anne' had leaf injury and yellowing in warm and hot areas, but the injury was considerably worse in the hot area.

The most impressive cultivar was 'Pink A ristocrat'. I t had abundant flowers that rose above the foliage for a prominent display of color. Thiscultivar would still need the warm growing conditions to avoid leaf tip injury and loss of vigor. 'Pink Aristocrat' had a superior root system and larger flowers when grown in the warm than the hot environment (Table3). Although ithad five flowers after 7 months, these early flowers were small and inconspicuous.
Flowers of this cultivar lasted longer than 'Patty Anne' and 'Purple Viking'. 'Royal Orange' and 'Royal Pink' had large, shiny flowers and a desirable foliage appearance when grown in the warm area. These two cultivars did not have an apparent decline in flower production when grown in the hot area, but did show slight leaf tip injury and marginal yellowing. 'Royal Red' was a beautiful plant in both growing areas with smaller heart-shaped leaves than the other two cultivars in this series and dense foliage, but it took longer to produce a crop with only a few flowers. Failure of this cultivar to flower timely should be investigated further. The production of numerous basal shoots and the lack of a few

Table 4. Six anthurium cultivars evaluated on 24 Aug., 13 months after planting and grown in a warm or hot environment $(2.54 \mathrm{~cm}=1$ inch).

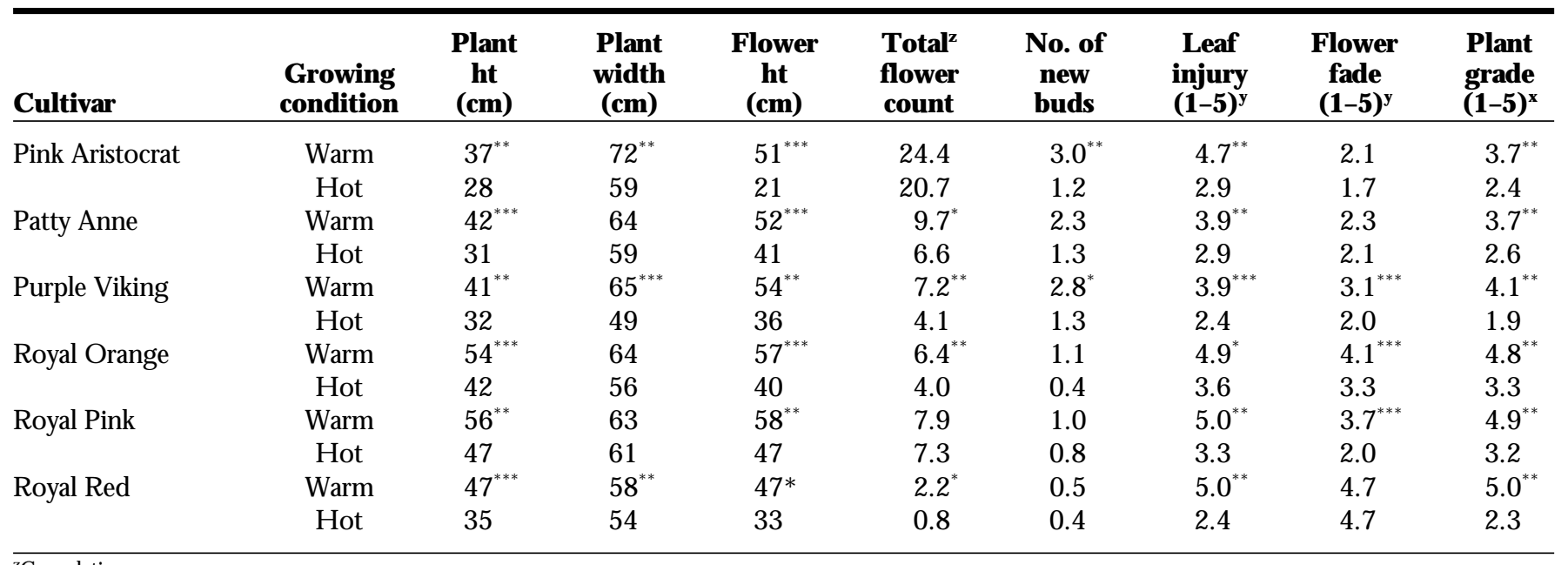

${ }^{\mathrm{z} C \text { umulative. }}$

y $5=$ No injury or fade to $1=$ severe injury or fade.

×5 = Excellent, 4 =good, $3=$ marketable, 2 = unmarketable, $1=$ very poor.

****,***Significant at $\mathrm{P}=0.05,0.01$, or 0.001 , respectively. 
strong lead shoots, possibly the result of tissue culture, might have contributed to the delayed flowering.

It was observed that once an anthurium shoot has started to bloom, a flower is produced in the axil of each successive, recently matured leaf of afew large lead shoots in each pot. Since the large shoots were capable of producing flowers and the small shoots were too small to bloom, $\mathrm{GA}_{3}$ had no effect on promoting flower production. H enny and $\mathrm{H}$ amilton (1992) reported, however, that Anthurium scherzerianum Schott 'Amazone' and 'Renate' responded to $\mathrm{GA}_{3}$ application and produced more flowers under high but not low light.

The number of flowers present on a plant is dependent upon how many large, flowering shoots are present and how fast the leaves on these shoots are produced. 'Pink Aristocrat', 'Patty Anne', and 'Purple Viking' have more flowering shoots and fewer small lateral shoots than plants in the 'Royal' series, therefore, they produced more flowers. $U$ nder the conditions of this study, the former three cultivars should be grown in 15-cm (6-inch) pots and be marketable in 7 to 8 months. 'Royal Orange' and 'Royal Pink' require 9 to 10 months to be produced in $15-\mathrm{cm}$ pots. It is not known a this time if the use of a lower nitrogen ratio fertilizer such as $10 \mathrm{~N}$ 13P-16.6K would enhance flowering. Future studies should address the light and fertilizer requirements of these anthurium cultivars.

\section{Literature cited}

Corr, B.E. and R.E. Widmer. 1987. Gibberellic acid increases flower number in Zantedeschia elliottiana and Z. R ehmannii. H ortScience 22:605-607.

H arbaugh, B.K. and G.J. Wilfret. 1979. Gibberellic acid $\left(\mathrm{GA}_{3}\right)$ stimulates flowering in Caladium hortulanum. HortScience 14:72-73.

Henny, R.J. and R.L. H amilton. 1992. Flowering of anthurium following treatment with gibberellic acid. HortScience 27:1328. 